\title{
PERANCANGAN APLIKASI ENKRIPSI DAN DEKRIPSI FILE BERBASIS WEB
}

\author{
Pas Mahyu Akhirianto ${ }^{1}$ \\ Anita B Wandanaya ${ }^{2}$ \\ Opan Mustopah $^{3}$
}

\author{
Dosen AMIK BSI Program Studi Teknik Komputer ${ }^{1}$, \\ Dosen STMIK Raharja Jurusan Teknik Informatika ${ }^{2}$ \\ Mahasiswa AMIK BSI Program Studi Teknik Komputer ${ }^{3}$ \\ J1. Kamal Raya No. 18, Cengkareng, Jakarta Barat ${ }^{1,3}$ \\ J1. Jendral Sudirman No. 40, Cikokol, Tangerang ${ }^{2}$ \\ email : pasmahyuar@gmail.com ${ }^{1}$,opan.mustopah@gmail.com ${ }^{2}$,anita@ raharja.info ${ }^{3}$
}

\begin{abstract}
ABSTRAK
Dalam perkembangan teknologi yang sudah sedemikian maju sekarang ini, terutama dalam bidang komunikasi dan informasi, menjaga kerahasiaan pribadi adalah hal yang mutlak harus di lakukan bagi setiap individu. Rapoport (dalam Soesilo, 1998) mendefinisikan privacy sebagai suatu kemampuan untuk mengontrol interaksi, kemampuan untuk memperoleh pilihan-pilihan dan kemampuan untuk mencapai interaksi yang diinginkan.Dewasa ini, banyak sekali hal yang dapat dilakukan dengan menggunakan internet, seperti berjualan, berinteraksi sosial melalui media sosial (Media Social) seperti Facebook, belajar, atau hanya sekedar membaca berita melalui portal media elektronik, dan lain sebagainya. Sebagian besar dari aktivitas yang dapat dilakukan diinternet, membutuhkan data pribadi dari penggunanya, disinilah isu privacy sangat diperhatikan. Seiring berkembangnya teknologi informasi dan komunikasi dalam internet, teknologi yang digunakan untuk melindungi seluruh data pribadi pengguna turut berkembang dan akan terus berkembang menjadi semakin canggih. Untuk itulah kami berinisiatif untuk membuat sebuah program aplikasi Endesapp, yang bertujuan untuk mempermudah seseorang ataupun instansi yang sering bertukar data berupa file melalui jaringan internet. Dengan begitu keamanan dalam menjaga data-data pribadi pun jadi meningkat serta kemungkinan tersebarnya data-data sensitif pun menjadi berkurang. Pada penelitian ini metode yang digunakan adalah membuat rancangan program berbentuk aplikasi enkripsi dan dekripsi file berbasis webdengan teknik kriptografi dengan jenis algoritma yang didukung adalah 3DES (Triple DES), AES-128 (Advanced Encyption Standard), AES-192 dan AES-256.
\end{abstract}

Kata Kunci: enkripsi, dekripsi, program enkripsi berbasis web.

\section{ABSTRACT}

In the development of technology that is so advanced today, especially in the field of communication and information, maintaining privacy is something that absolutely must be done for each individual. Rapoport (in Soesilo, 1998) defines privacy as an ability to control the 
interaction, the ability to acquire options and the ability to achieve the desired interaction. Nowadays, a lot of things that can be done by using the internet, such as selling, social interacting through social media (Social Media) such as Facebook, learn, or just read the news through the portal of electronic media, and so forth. Most of the activities that can be done on the internet, requires personal data of its users, where the issue of privacy is of considerable concern. As the development of information and communication technology in this case the Internet, the technology used to protect all personal data users also grown and will continue to evolve into more sophisticated. For this reason the author took the initiative to create a Endesapp application program, which aims to facilitate a person or agency who frequently exchange data in the form of files through the Internet. With so security in maintaining personal data even be increased as well as the possibility of the spread of sensitive data has been poor. In this study, the method used is to design programs shaped application file encryption and decryption web-based cryptographic techniques to the type of algorithm that is supported is 3DES ( Triple DES ), AES - 128 (Advanced encyption Standard), AES - 192 and AES - 256.

Keywords: encryption, decryption, web-based encryption program

\section{PENDAHULUAN}

Dalam perkembangan teknologi yang sudah sedemikian maju sekarang ini, terutama dalam bidang komunikasi dan informasi, menjaga kerahasiaan pribadi (Privacy) adalah hal yang mutlak harus dilakukan bagi setiap individu. Rapoport (dalam Soesilo, 1998) mendefinisikan privacy sebagai suatu kemampuan untuk mengontrol interaksi, kemampuan untuk memperoleh pilihan-pilihan dan kemampuan untuk mencapai interaksi yang diinginkan ${ }^{[1]}$.

Dewasa ini, banyak sekali hal yang dapat dilakukan dengan menggunakan internet, seperti berjualan, berinteraksi sosial melalui media sosial (Media Social) seperti Facebook, belajar, atau hanya sekedar membaca berita melalui portal media elektronik, dan lain sebagainya. Sebagian besar dari aktivitas yang dapat di lakukan di internet, membutuhkan data pribadi dari penggunanya, disinilah isu privacy sangat diperhatikan. Seiring berkembangnya teknologi informasi dan komunikasi dalam hal ini internet, teknologi yang di gunakan untuk melindungi seluruh data pribadi pengguna turut berkembang dan akan terus berkembang menjadi semakin canggih.

Salah satu teknologi vital yang sangat di butuhkan dalam melindungi data pribadi pengguna yaitu kriptografi (Crypthography) atau sering kita sebut dengan istilah enkripsi (Encryption). Hampir seluruh metode pengamanan data, di berbagai macam bidang teknologi menggunakan teknologi enkripsi sebagai metode untuk melindungi data mereka. Selain istilah enkripsi, didalam kriptografi, dikenal juga istilah dekripsi (Decryption).

Dalam kamus bahasa Inggris Oxford diberikan pengertian kriptografi sebagai berikut ${ }^{[2]}$ :

"Sebuah teknik rahasia dalam penulisan, dengan karakter khusus, dengan menggunakan huruf dan karakter di luar bentuk aslinya, atau dengan metode-metode lain yang hanya dapat dipahami oleh pihak-pihak yang memproses kunci, juga semua hal yang ditulis dengan cara seperti ini". Jadi secara umum dapat diartikan sebagai seni menulis atau memecahkan cipher (Talbot da welsh, 2006) $^{[2]}$.

Menurut Request for Comments (RFC)[2] "kriptografi merupakan ilmu matematika yang berhubungan dengan transformasi data untuk membuat artinya tidak dapat dipahami (untuk menyembunyikan maknanya), mencegahnya dari perubahan tanpa izin, atau mencegahnya dari 
penggunaan tidak sah. Jika transformasinya dapat dikembalikan, kriptografi juga bisa diartikan sebagai proses mengubah kembali data yang ter-enkripsi menjadi bentuk yang dapat dipahami". Artinya, kriptografi dapat diartikan sebagai proses untuk melindungi data dalam arti yang luas $\left(\right.$ Oppliger, 2005) ${ }^{[2]}$.

Dari penjelasan diatas, dapat ditarik pengertian bahwa enkripsi adalah proses mengamankan suatu informasi dengan membuat informasi tersebut tidak bisa dibaca tanpa bantuan pengetahuan khusus. Teknologi lain yang menggunakanilmu kriptografi adalah Message Authentication Code (MAC) atau Digital Signature ${ }^{[3]}$. Sedangkan dekripsi adalah kebalikan proses dari enkripsi dimana membuat sebuah informasi yang telah atau sudah ter-enkripsi, kembali dapat dibaca dan dipahami.

Algoritma menggambarkan sebuah prosedur komputasi yang terdiri dari variabel input dan menghasilkan output yang berhubungan (Oppliger, 2005). Algoritma kriptografi atau sering disebut dengan cipher adalah suatu fungsi matematis yang digunakan untuk melakukan enkripsi dan dekripsi (Schneier, 1996). ${ }^{[2]}$

Sering sekali kita mendengar berita mengenai bocor-nya informasi seseorang ke ruang publik. Kondisi seperti ini tentu sangat mengkhawatirkan, sebab di zaman yang sudah serba canggih ini, tentunya untuk mendapatkan sebuah informasi bukanlah sebuah hal sulit untuk dilakukan. Orang yang tidak memiliki otoritas bisa saja mengakses file pribadi kita yang mungkin sudah tersebar di internet.

Untuk mengatasi masalah tersebut, pada penelitian ini penulis membuat sebuah aplikasi untuk mengamankan data pribadi di media sosial dengan merancang aplikasi enkripsi dan dekripsi file berbasis web dengan teknik kriptografi dengan jenis algoritma yang didukung adalah 3DES (Triple DES), AES-128 (Advanced Encyption Standard), AES-192 dan AES-256.

\section{METODE PENELITIAN}

Metode penelitian yang digunakan dalam membuat penelitian dan perancangan program adalah sebagai berikut :

1. Pengamatan /Observation.

Pengamatan dilakukan berdasarkan latar belakang secara khusus.

2. Wawancara/Interview.

Wawancara dilakukan dengan cara konsultasi dengan pakar dan rekan sejawat.

3. Kepustakaan/Library.

Sumber referensi dalam pembuatan karya ilmiah dan perancangan program diantaranya konsep, desain, contoh script aplikasi program dan implementasi program didapat dari internet, jurnal penelitian, buku dan referensi lainnya.

Membuat rancangan program berbentuk aplikasi enkripsi dan dekripsi file berbasis web.

\section{LITERATURE REVIEW}

Untuk dapat mengembangkan dan menyempurnakan penelitian ini, maka perlu dilakukan studi pustaka (literature review) sebagai salah satu penerapan metode penelitian yang akan dilakukan sebagai bahan perbandingan, diantaranya sbb :

1. Penelitian yang dilakukan oleh Langit Da Sylva P, Dessyanto B.P dan Heriyanto (2013) dari UPN "Veteran", Yogyakarta, dengan judul " Aplikasi Enkripsi dan Dekripsi File dengan menggunakan AES (Advanced Encryption Standard) Algoritma Rijndael Pada Sistem Operasi Android". Permasalahan yang diangkat penulis adalah masalah pengamanan file pada perangkat smartphone yang menggunakan sistem operasi android sehingga dalam penilitian ini dibuat sistem aplikasi pengaman file drngan menggunakan AES algoritma 
Rijndael. Metode yang digunakan dalam perancangan dan pembuatan perangkat lunak ini adalah Metode GRAPPLE (Gudellines for Rapid Application Engineering) dan bahasa pemrograman yang digunakan adalah Java.

2. Penelitian yang dilakukan oleh Siswo Wardoyo, Zaldi Imanullah dan Rian Fahrizal (2016) dari Jurusan Teknik Elektro, Fakultas Teknik Universitas Andalas, Padang. Penelitian ini berjudul "Enkripsi dan Dekripsi File dengan Algoritma Blowfish Pada Perangkat Mobile Berbasis Android".

Permasalahan pada penelitian ini adalah keamanan data pada ponsel yang memiliki sistem operasi android versi 2.3. Penelitian ini menggunakan Metode Kriptografi yang digunakan untuk mengamankan data dalam bentuk file dengan mengenkripsi file sehingga orang lain tidak berhak mengetahui file yang sifatnya pribadi dan rahasia. Salah satu metode kriptografi adalah algoritma Blowfish yang merupakan algoritma yang menggunakan kunci simetris untuk melakukan enkripsi dan dekripsi. Aplikasi yang dibangun ini dapat melakukan enkripsi file berbentuk gambar, video, dan dokumen. Perangkat lunak yang digunakan untuk membangun aplikasi ini adalah Eclipse.

3. Penelitian yang dilakukan oleh Winda Erika, Heni Rachmawati dan Ibnu Surya (2012) dari Jurusan Teknik Informatika Politeknik Caltex Riau, Pakanbaru, dengan judul " Enkripsi Teks Surat Elektronik (E-mail) berbasis Alogaritma Rivest Shamir Adleman (RSA) ". Permasalahan pada penelitian ini adalah keamanan data e-mail. Penelitian ini teknik kriptografi asimetri yaitu Algoritma RSA untuk menjaga kerahasiaan data. Perancangan proses aplikasi dimulai dengan proses pembangkitan kunci oleh penerima untuk memperoleh nilai $\mathrm{N}$ (hasil perkalian dua bilangan prima), kunci public dan kunci private. Kunci private disimpan oleh penerima kemudian nilai $\mathrm{N}$ dan kunci public dikirim kepada pengirim teks email. Pengirim mengenkripsi teks menggunakan nilai $\mathrm{N}$ dan kunci public, sedangkan penerima mendekripsi teks menggunakan kunci private. Aplikasi dibangun menggunakan bahasa pemrograman Java (Netbeans 7.0) dan Mail server yang digunakan adalah Java Apache Mail Enterprise Server (James).

\section{PEMBAHASAN}

\section{Use Case Diagram}

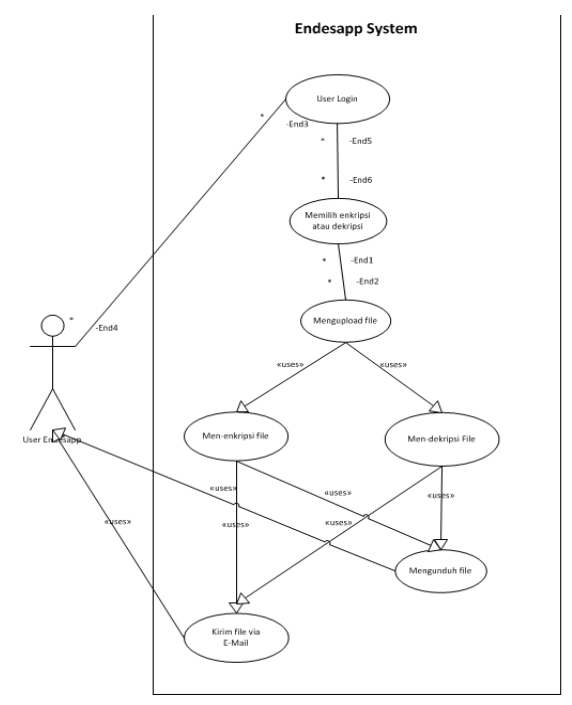

Gambar 1.

Use Case Diagram Endesapp 
Prosedur dalam program aplikasi yang dibuat adalah:

a. User (pengguna) mengakses website Endesapp dengan urlwww.endesapp.co.vu menggunakan browser yang disarankan seperti: Google Chrome, Mozilla Firefox, dan Opera.

b. User memilih menu "Start", dan memilih apakah ingin mendaftar (Sign Up) jika belum memiliki akun atau masuk (Sign In) jika sudah memiliki akun.

c. Lalu masuk di halaman user, user memilih apakah ingin melakukan proses dekripsi file atau enkripsi file.

d. Setelah user memilih proses yang ingin dilakukan, user memilih file yang akan di proses. Jenis file yang didukung dalam proses enkripsi dan dekripsi adalah *pdf, *txt, *text dan *csv.

e. User memilih jenis alogirtma yang digunakan dalam proses enkripsi dan dekripsi. Jenis algoritma yang didukung adalah 3DES (Triple DES), AES-128 (Advanced Encyption Standard), AES-192 dan AES-256.

f. User memilih pilihan tambahan seperti memilih apakah mengizinkan Endesapp menyimpan file yang telah di enkripsi (khusus untuk proses enkripsi) atau tidak, apakah ingin menggunakan customkey (user menentukan sendiri kunci yang akan digunakan dalam proses enkripsi) atau tidak dan metode penerimaan file yang telah di enkripsi atau di dekripsi apakah melalui email atau direct terunduh melalui browser.

g. Jika proses enkripsi atau dekripsi berhasil, user akan segera mendapatkan file hasil dari proses tersebut sesuai dengan metode penerimaan file yang ada di prosedur nomor tujuh.

\section{Flowchart}

a. Flowchart Home Page

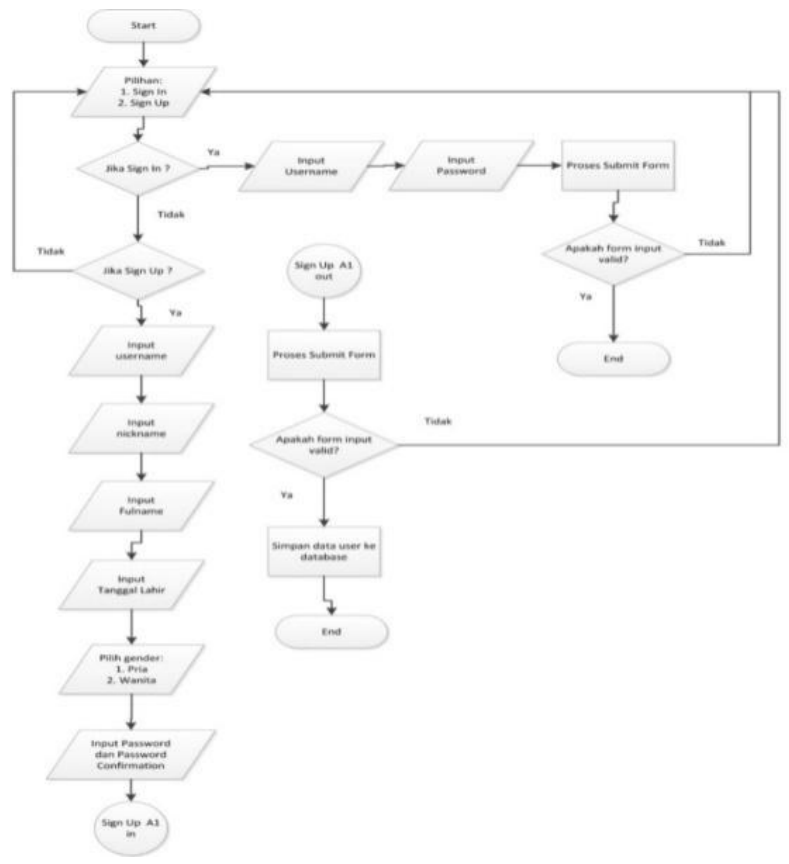

Gambar 2

Flowchart proses halaman utama. 
b. Flowchart Halaman User

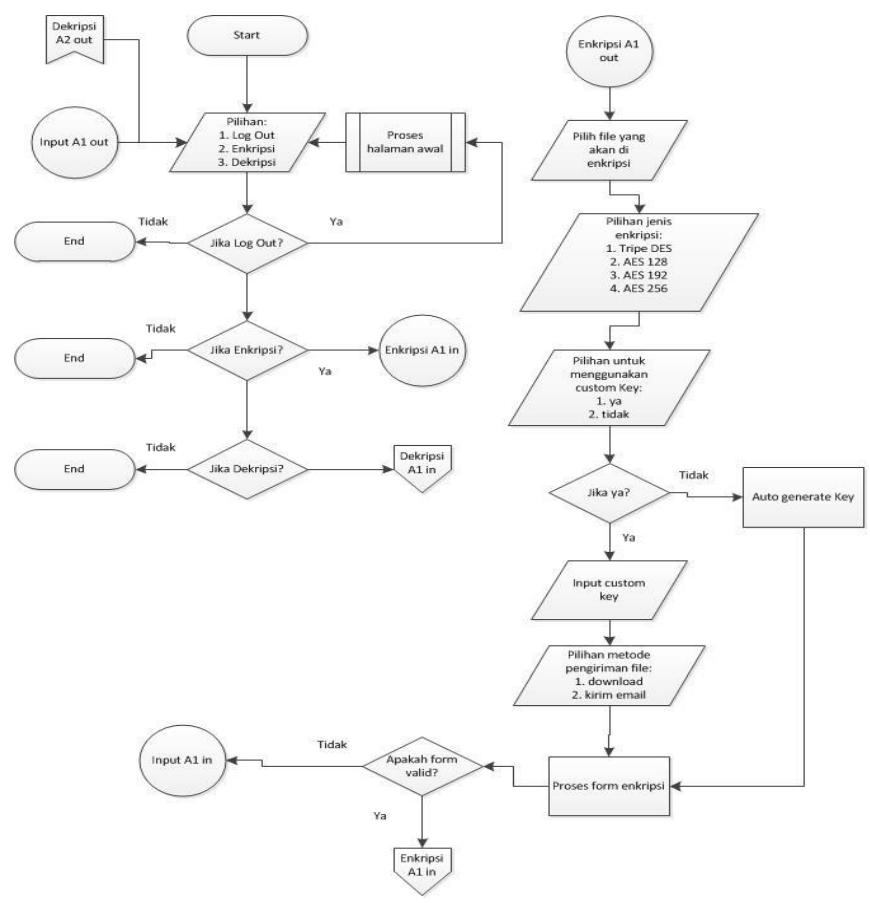

Gambar 3

Flowchart proses halaman user bagian pertama

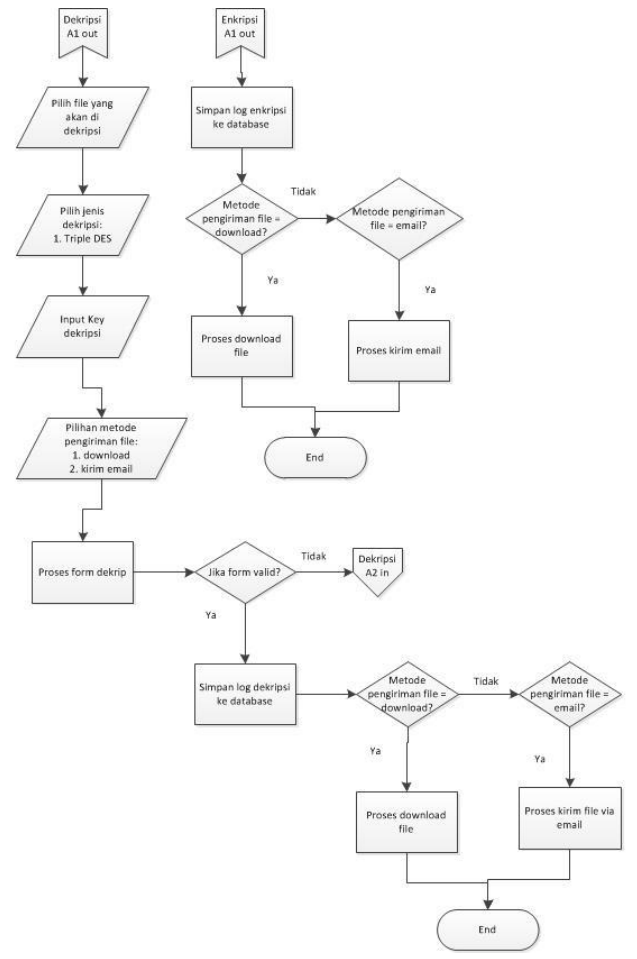

Gambar 4

Flowchart proses halaman user bagian kedua 


\section{Spesifikasi Rancangan Program}

\section{a. Spesifikasi Bentuk Masukan}

Bentuk spesifikasi dokumen-dokumen masukan yang digunakan pada sistem program Endesapp harus berupa file dengan ektensi file pdf atau PDF, txt atau TXT, text atau TEXT serta csv atau CSV.

1. Nama Dokumen : *file dengan ekstensi yang telah disebutkan.

Fungsi : File yang akan didekripsi atau dienkripsi.

Sumber : Direktori lokal user.

Tujuan : Proses enkripsi atau dekripsi.

Media : : Browser.

Jumlah : Satu file.

Frekuensi $\quad$ : Setiap memulai proses enkripsi atau dekripsi.

Bentuk :-

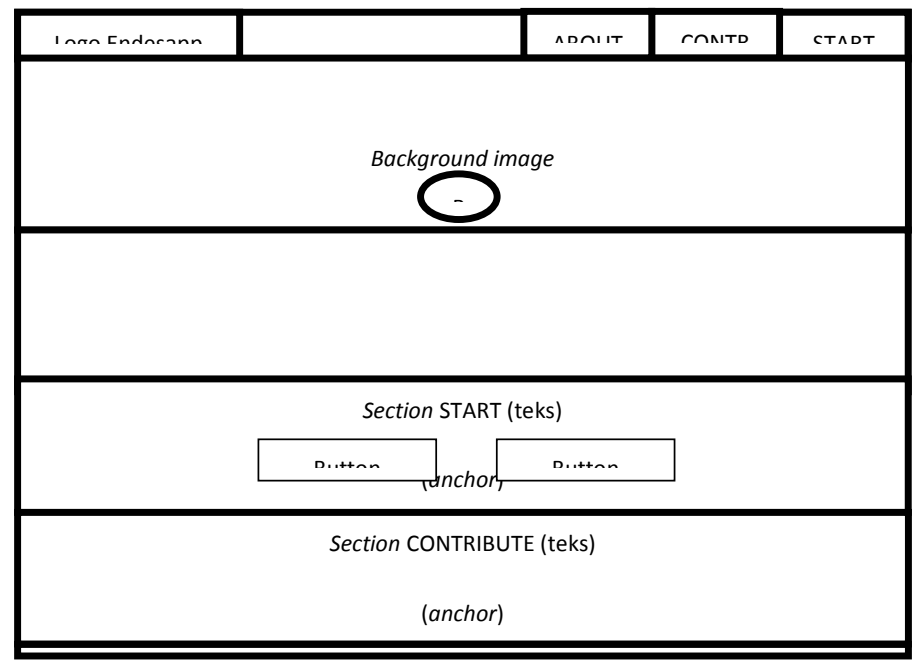

Gambar 5

Tampilan rancangan program bentuk masukan

\section{Proses}

1) Pada home/index.html.haml, terdapat 3 (tiga) menu utama, yakni 'ABOUT', 'CONTRIBUTE' dan 'START'. Jika user memilih menu 'ABOUT', maka halaman akan otomatis scrolling ke bawah menuju section penjelasan mengenai apa itu program aplikasi Endesapp. Jika user memilih menu 'CONTRIBUTE', maka user halaman akan otomatis scrolling ke bawa menuju section penjelasan bagaimana cara agar bisa berkontribusi dalam pengembangan program aplikasi Endesapp. Dan terakhir jika user memilih 'START', maka sama seperti menu-menu sebelumnya, halaman akan otomatis scrolling, ke section untuk masuk ataupun mendaftar di aplikasi Endesapp.

2) Di section 'START', user akan diberikan 2 (dua) pilihan apakah ingin masuk (sign in) jika sudah memiliki akun di aplikasi Endesapp atau mendaftar (sign up) jika belum memiliki akun. 
3) Setelah user memasukkan data sesuai dengan yang dibutuhkan masing-masing form dan sudah tervalidasi, maka halaman akan redirect menuju halaman user.

\section{b. Spesifikasi Bentuk Keluaran}

Bentuk spesifikasi dokumen-dokumen keluaran yang digunakan pada sistem program Endesapp adalah:

1. Nama Dokumen : decrypted_*prefix atau encrypted_*prefix (sesuai dengan file masukan).
Fungsi
: File hasil proses enkripsi atau dekripsi.
Sumber
: File yang di input user.
Tujuan
: Direktori lokal user.
Media
: Browser
Jumlah
: Satu file.
Frekuensi
: Setiap selesai proses enkripsi atau dekripsi.
Bentuk

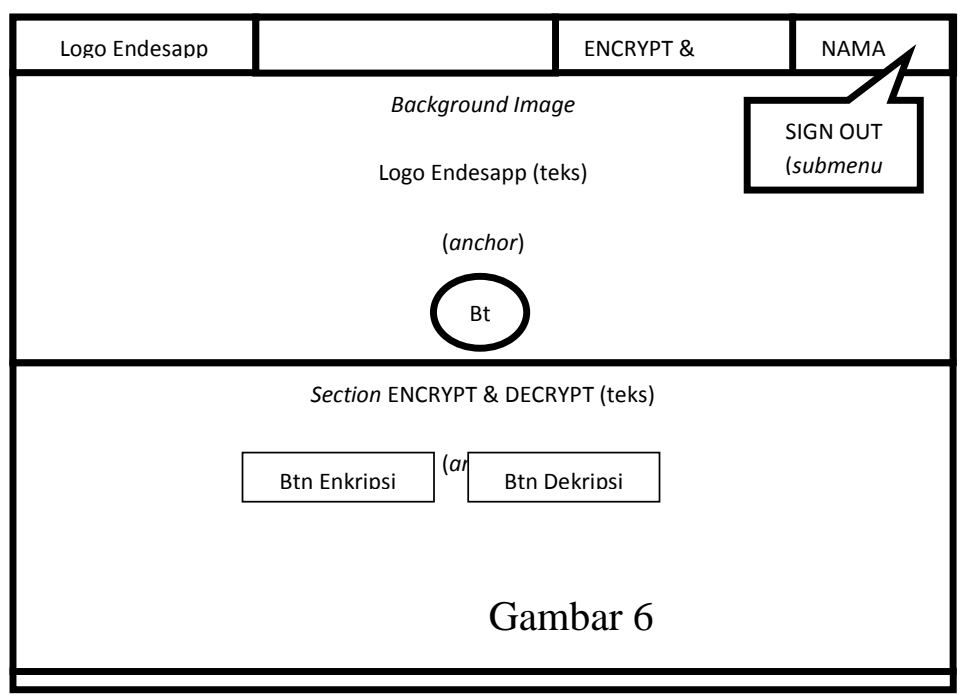

Proses:

Tampilan rancangan program bentuk keluaran

a. Pada sistems/index.html.haml, terdapat 2 (dua) menu utama yakni 'ENCRYPT \& DECRYPT' dan 'SIGN OUT (NAMA USER)'. Jika user memilih menu pertama, maka halaman akan otomatis scrolling menuju section enkripsi dan dekripsi. Disini user kembali diberikan pilihan apakah ingin melakukan proses enkripsi atau dekripsi file.

b. Setelah user memilih proses yang ingin dilakukan, lalu memasukkan data yang dibutuhkan sesuai dengan proses yang dipilih dan data yang dimasukkan valid, maka akan muncul notifikasi bahwa proses telah berhasil dan jika tidak maka akan muncul notifikasi bahwa data yang dimasukkan kemungkinan ada yang tidak valid.

c. Jika user memilih menu 'SIGN OUT', maka user melakukan proses keluar dari aplikasi dan akan langsung di redirect kembali ke halaman utama. 


\section{Spesifikasi File}

Berikut adalah spesifikasi file yang ada didalam program apliaski Endesapp:

1. Spesifikasi File Log Enkripsi
Nama File
: m_encrypts.
Akronim
: m_encrypts.
Fungsi
:Menyimpan $\log$
Tipe File
: File Master.
Organisasi File
: Index Sequential.
Akses File
: Random.
Media
: Hard Disk.
Kunci Field
: encrypt_id
Software
: PostgreSQL dan PgAdmin.

Tabel 1. Spesifikasi File Log Enkripsi

\begin{tabular}{|c|l|l|c|c|}
\hline No & \multicolumn{1}{|c|}{ Field } & Tipe & $\begin{array}{c}\text { Pan } \\
\text { jang }\end{array}$ & $\begin{array}{c}\text { Keterang } \\
\text { an }\end{array}$ \\
\hline 1. & Id & Serial & - & \\
\hline 2. & Encrypt_id & Bigint & - & Primary \\
\hline 3. & Encryption_type & Integer & - & \\
\hline 4. & File_name & Varchar & 255 & \\
\hline 5. & Created_by & Varchar & 255 & \\
\hline 6. & Updated_by & Varchar & 255 & \\
\hline 7. & Created_at & Timestamp & - & \\
\hline 8. & Updated_at & Timestamp & - & \\
\hline 9. & Username & Varchar & 100 & \\
\hline 10. & Hashed_keys & Text & - & \\
\hline 11. & Encrypted_keys & Text & - & \\
\hline 12. & Is_keep_file & Boolean & - & \\
\hline 13. & Is_custom_key & Boolean & - & \\
\hline
\end{tabular}

2. Spesifikasi File Log Dekripsi

Nama File : m_decrypts.

Akronim : m_decrypts.

Fungsi : Menyimpan log

Tipe File : File Master

Organisasi File : Index Sequential.

Akses File : Random.

Media : Hard Disk.

Kunci Field : decrypt_id.

Software : PostgreSQL dan PgAdmin

Tabel 2. Spesifikasi File Log Dekripsi

\begin{tabular}{|c|l|l|c|c|}
\hline No & \multicolumn{1}{|c|}{ Akronim } & \multicolumn{1}{c|}{ Tipe } & Panjang & Ket \\
\hline 1. & Id & Serial & - & \\
\hline 2. & Decrypt_id & Bigint & - & $\begin{array}{c}\text { Primar } \\
\text { y }\end{array}$ \\
\hline 3. & Decryption_type & Integer & 100 & \\
\hline 4. & File_name & Varchar & 255 & \\
\hline 5. & Created_by & Varchar & 255 & \\
\hline 6. & Updated_by & Varchar & 255 & \\
\hline 7. & Created_at & Timestamp & - & \\
\hline 8. & Updated_at & Timestamp & - & \\
\hline 9. & Username & Varchar & 100 & \\
\hline 10. & Receive_type & Varchar & 150 & \\
\hline
\end{tabular}


3. Spesifikasi File User

Nama File : User

Akronim : a_users

Fungsi : Menyimpan daftar user

Tipe File : File Master.

Organisasi File : Index Sequential.

Akses File : Random.

Media : Hard Disk.

Kunci Field : Username

Software : PostgreSQL dan PgAdmin.

Tabel 3.Spesifikasi File User

\begin{tabular}{|c|l|l|c|c|}
\hline No & \multicolumn{1}{|c|}{ Akronim } & \multicolumn{1}{|c|}{ Tipe } & $\begin{array}{c}\text { Panja } \\
\text { ng }\end{array}$ & Ket \\
\hline 1. & Id & Serial & - & \\
\hline 2. & Username & Varchar & 100 & Primary \\
\hline 3. & Password & Varchar & 255 & \\
\hline 4. & $\begin{array}{l}\text { Encrypted_passw } \\
\text { ord }\end{array}$ & Varchar & 255 & \\
\hline 5. & Nickname & Varchar & 100 & \\
\hline 6. & Fullname & Varchar & 255 & \\
\hline 7. & Gender & Integer & - & \\
\hline 8. & Birthdate & Date & - & \\
\hline 9. & Created_at & $\begin{array}{l}\text { Timestam } \\
\text { p }\end{array}$ & - & \\
\hline 10. & Updated_at & $\begin{array}{l}\text { Timestam } \\
\text { p }\end{array}$ & - & \\
\hline 11. & Login_count & Integer & - & \\
\hline 12. & $\begin{array}{l}\text { Uniq_folder_nam } \\
\text { e }\end{array}$ & Varchar & 100 & \\
\hline
\end{tabular}

\section{HIPO}

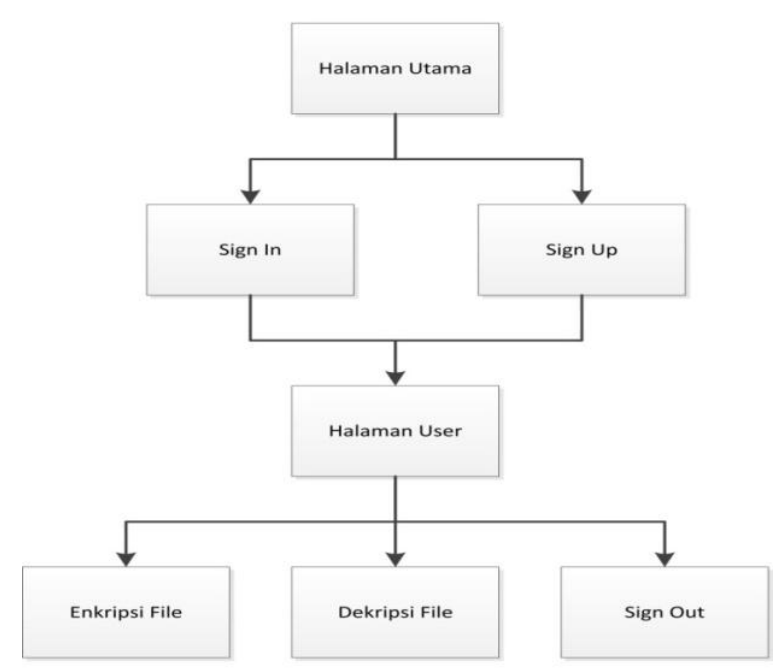

Gambar 7. HIPO Endesapp 


\section{Spesifikasi Program}

Adapun spesifikasi program yang ada didalam aplikasi Endesapp adalah sebagai berikut:

1. Halaman Utama

Nama Program : Home

Akronim : index.html

Fungsi $\quad$ : Sebagai tampilan awal atau tampilan utama dari aplikasi Endesapp

Index Program :-

Bahasa Program : : Ruby, HTML, JavaScript, HAML.

Bentuk Tampilan : : Lihat Gambar 5.

2. Halaman User

Nama Program : Sistems

Akronim : index.html

Fungsi : Tampilan halaman user setelah melakukan proses sign in atau sign up.

Index Program : :

Bahasa Program : : Ruby, HTML, JavaScript, HAML

Bentuk Tampilan : : Lihat Gambar 6.

\section{KESIMPULAN}

Berdasarkan uraian-uraian yang telah dijelaskan di atas, dapat ditarik beberapa kesimpulan yakni:

1. Kriptografi saat ini sudah tidak bisa dipisahkan lagi dengan kehidupan saat ini yang selalu terhubung dengan dunia teknologi informasi untuk menjaga kerahasiaan data pribadi para penggunanya.

2. Hampir seluruh bidang industri yang ada saat ini menggunakan kriptografisebagai metode untuk melindungi data-data sensitif mereka seperti data keuangan dan sebagainya.

3. Secara garis besar terdapat 2 (dua) jenis algoritmakriptografi, yaitu algoritmasimetris(algoritma konvensional) dan algoritmaasimetris(algoritmakunci publik).

4. Terdapat 4 (empat) tujuan dari kriptografi, yaitu kerahasiaan (confidentiality), integritas data, otentifikasi dan nirpenyangkalan (non-repudiation).

5. Pengguna (khususnya pengguna internet) dapat meningkatkan keamanannya dalam menjaga data-data pribadi mereka dengan mengunjungi situs-situs yang sudah terpercaya dan tidak sembarang mengklik link-linkwebsite yang mencurigakan.

6. Dengan menggunakan web browser terbaru, pengguna internetjuga bisa menghindari tercurinya data-data sensitif saat atau sedang melakukan penjelajahan di dunia maya, karena pihak pengembang web browser selalu menyempurnakan aplikasi mereka dengan menutup celah keamanan atau biasa disebut dengan bug.

\section{DAFTAR PUSTAKA}

[1] Helmi Prasetyo Yuwinanto "Jurnal Kebijakan Informasi dan Privacy" olehDepartemen Informasi dan PerpustakaanFISIP, Universitas Airlangga. J1. Airlangga 46 Surabaya, 60286, Indonesia. Telp. (031) 5011744. E-Mail: nanto_pras@yahoo.com,Diakses pada tanggal 24 April 2016 http://docplayer.info/99283-Kebijakan-informasi-dan-privacy-helmy-prasetyoyuwinanto-1.html. 
[2] Materi kriptografi Bab II (Landasan Teori / Pengertian Kriptografi ) Universitas $\begin{array}{llllll}\text { SumatraUtara. } & \text { Diakses } & \text { pada } & \text { tanggal } & 24\end{array}$ http://repository.usu.ac.id/bitstream/123456789/34717/4/Chapter\%20II.pdf.

[3] Wikipedia Indonesia "Enkripsi “ Diakses pada tanggal 24 April 2016 https://id.wikipedia.org/wiki/Enkripsi.

[4] Langit Da Sylva P, Dessyanto B.P dan Heriyanto.2013. “Aplikasi Enkripsi dan Dekripsi File dengan menggunakan AES (Advanced Encryption Standard) Algoritma Rijndael Pada Sistem Operasi Android”. Universitas Pembangunan Nasional "Veteran", Yogyakarta.

[5] Wardoyo,Siswo. Imanullah,Zaldi dan Fahrizal, Rian (2016). “ Enkripsi dan Dekripsi File dengan Algoritma Blowfish Pada Perangkat Mobile Berbasis Android”. Jurusan Teknik Elektro, Fakultas Teknik Universitas Andalas, Padang.

[6] Winda Erika, Heni Rachmawati dan Ibnu Surya . 2012. "Enkripsi Teks Surat Elektronik (Email) berbasis Alogaritma Rivest Shamir Adleman (RSA) “. Jurusan Teknik Informatika Politeknik Caltex Riau, Pakanbaru, 